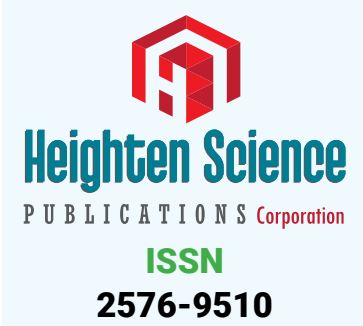

*Address for Correspondence: Fatma I Abo El-Ela, Lecturer, Department of Pharmacology, Faculty of Veterinary Medicine, Beni-Suef University 62511, Egypt, Tel: +201152460404; Fax: +20822327982; Email: fa.pharma@yahoo. com; fatma.aboel3la@vet.bsu.edu.eg

Submitted: 13 September 2017

Approved: 11 December 2017

Published: 12 December 2017

Copyright: @ 2017 Abo El-Ela Fl, et al. This is an open access article distributed under the Creative Commons Attribution License, which permits unrestricted use, distribution, and reproduction in any medium, provided the original work is properly cited.

Keywords: Florfenicol; Vit E; Single; Multiple; Pharmacokinetics; Broilers

\title{
Influence of Vitamin E on the Disposition Kinetics of Florfenicol after single and multiple oral administrations in Broiler Chickens
}

\author{
Fatma Ibrahim Abo El-Ela ${ }^{1 *}$ Hossny Awad El-Banna², Manal B \\ El-Deen ${ }^{3}$ and Tohamy MA ${ }^{4}$ \\ 'Lecturer, Department of Pharmacology, Faculty of Veterinary Medicine, Beni-Suef University, \\ Egypt \\ ${ }^{2}$ Professor \& Head, Department of Pharmacology, Faculty of Veterinary Medicine, Cairo \\ University, Giza, Egypt \\ ${ }^{3}$ Researcher, Animal Research, Institute of Animal Reproduction Research, Al-Harm, Egypt \\ ${ }^{4}$ Professor, Department of Pharmacology, Faculty of Veterinary Medicine, Beni-Suef University, \\ Beni-Suef 62511, Egypt
}

\section{Abstract}

Investigation the influences of vitamin (vit) E over a period of 5 days on the pharmacokinetics of florfenicol after single and multiple oral administrations in broiler chickens. Total of 12 broiler chickens had been taken single and multiple oral administrations of florfenicol $(30 \mathrm{mg} / \mathrm{kg})$ alone or pre-treated with vit $\mathrm{E}(2 \mathrm{mg} / \mathrm{kg})$. The serum concentrations of florfenicol were determined using microbiological assay with Bacillus subtilis (ATCC 25922) as a tested microorganism. The mean serum concentrations of florfenicol alone were markedly lower when compared with florfenicol pre-treated with vit $\mathrm{E}$ after single and multiple dosing. The peak serum concentrations $\left(C_{\max }\right)$ were $5.9 \pm 0.46,7.48 \pm 0.3 \mathrm{ug} / \mathrm{ml}$, absorption half-life $\left(\mathrm{t}_{0.5 \mathrm{ab}}\right)$ of $0.51 \pm 0.06,0.71 \pm 0.1 \mathrm{~h}$ and elimination halflife $\left(\mathrm{t}_{0.5 \mathrm{e}}\right)$ of $2.72 \pm 0.34,3.34 \pm 0.5$ after single florfenicol alone and florfenicol pre-treated with vit $\mathrm{E}$ respectively. While, after multiple dosing, $\left(\mathrm{C}_{\max }\right)$ were $7.4 \pm 0.3,8.04 \pm 0.3 \mathrm{ug} / \mathrm{ml},\left(\mathrm{t}_{0.5 \mathrm{ab}}\right) 0.82 \pm 0.04,0.81 \pm 0.04 \mathrm{~h}$ and $\left(\mathrm{t}_{0.5 \mathrm{el}}\right)$ $3.77 \pm 0.2,4.52 \pm 0.7 \mathrm{~h}$ after multiple dosing of florfenicol alone and florfenicol pre-treated with vit $\mathrm{E}$ respectively. In conclusion Vit $\mathrm{E}$ alter the disposition kinetics of florfenicol after single and multiple oral administrations as, vit $\mathrm{E}$ allows prolongation of the duration of action for more 24 and $48 \mathrm{~h}$ of the drug concentration in the serum indicated by prolonged elimination half-lives and MRT reflecting the importance of this combination for the drug duration in serum but the increase in the serum concentration of florfenicol increasing its efficacy not toxicity as florfenicol of wide safety margin so, it's advisable for poultry farms owners to use this combinations.

\section{Introduction}

Florfenicol is only used in veterinary medicine and has been approved by the Committee for Veterinary Medicinal Products (the European Agency for the Evaluation of Medical Products-EMEA). It is a potent agent used as an alternative to chloramphenicol. It was introduced for the treatment of susceptible bacterial diseases in cattle, fish, pigs and chickens in the mid-1990s [1]. The pharmacokinetic studies of florfenicol have been conducted in cats, dogs [2], rabbits [3], alpacas [4], and chickens [5] However, in our knowledge there is no information available on the influence of vit $\mathrm{E}$ on the pharmacokinetic behavior of florfenicol in animals. The Pharmacokinetic interactions occur when one drug alters the delivery of another to its target besides drugs may alter the absorption, distribution, or elimination of one another [6]. A particular drug may have no action on a targeted tissue whatsoever but may modify another drug's influence by varying its concentration available to produce an effect. This interaction may result either in diminished effects or drug potentiation [7]. In poultry farms, the 
drug combinations are usually used. In these farms drug interactions may occur. Theses interactions have been studied in chickens [8-11]. For instance, the coccidiostatics and the nutritive antibiotics may significantly alter the pharmacokinetics of several antibacterial drugs (tylosin, sulfadimidine and apramycin) when administered together. The simultaneous administration of antibiotics and vitamins is routinely used. Ascorbic acid influences metabolic pathways in the organism and may thus affect oleandamycin body disposition [12].

Antibiotics constitute a family of drug, which taken as a group, represents one of the most frequently prescribed around the world. Thus, not surprisingly antibiotic list on the top of causes of drug induced many side effects [13]. Supplementation of antioxidants can be considered as the alternative method for chelation therapy besides many studies indicate to protective effects of vitamins A, C and E against many alteration caused by organophosphate insecticides and some medicines that induced hepatotoxicity $[14,15]$. In our knowledge no data were available in the literature related to the effect of vit $\mathrm{E}$ on the disposition kinetics of florfenicol. The aims of this study were to evaluate if vit $\mathrm{E}$ affects or change any of the pharmacokinetics of florfenicol after single and multiple oral administration in broiler chickens at dose of $2 \mathrm{mg} / \mathrm{kg}$ b.wt. (vit E) and $30 \mathrm{mg} / \mathrm{kg}$ b.wt. (florfenicol).

\section{Materials and Methods}

\section{Chickens and husbundry}

The work had been experimented on 12 broiler chickens with an average body weight from 1.280 to $2.00 \mathrm{~kg}$ and 45 days old, birds divided into four groups. These birds were obtained from a special poultry farm in Beni-Suef Governorate. The chickens were fed on balanced commercial ration and water ad-libitum. They were kept under good hygienic conditions and left without treatment for 15 day before the experiment for acclimatization and ensuring complete clearance of any antibacterial drugs. The experiments were carried out according to the National regulations animal welfare and institutional animal Ethical Committee (IAEC) of Beni-Suef University which approved for animal uses.

\section{Drugs}

Florfenicol: was kindly provided by Pharma-Swede company, Egypt as a white powder (98\%), highly soluble in N, N-Di methyl formamide according to the manufacture instructions.

Vitamin E: Vit E supplemented as a white powder in the form of $\alpha$-tocopherol acetate $50 \%$ with target amount of $2 \mathrm{mg}$ dI $\alpha$-tocopherol acetate/ $\mathrm{kg}$ of body weight, throughout the remainder of this manuscript $\alpha$-tocopherol will be referred as Vit E. It was obtained kindly from Pharma Swede Pharmaceutical Company.

\section{Experimental design}

Single dose study: -12 apparently healthy broiler chickens had been divided into two (2) groups, the first group administered florfenicol $30 \mathrm{mg} / \mathrm{kg}$ b.wt [16]. As a single oral dose and the second group were given vit E ( $2 \mathrm{mg} / \mathrm{kg}$ b.wt.) firstly $2 \mathrm{~h}$ before starting florfenicol administration then florfenicol $30 \mathrm{mg} / \mathrm{kg} \mathrm{b.wt}$. Had been given later as a single oral dose (intra-crop route). Blood samples ( $1 \mathrm{ml}$ each) were taken from wing vein just after 5,10,15,30 minutes, 1,2,4,6,8,12,24,48,72 and 96 hours post drug administration. All blood samples were left to clot for 30 minutes, centrifuged at 3000 r.p.m. for 15 minutes and the obtained clear serum was transferred to eppendorff's tubes and kept in deep freeze $\left(-20^{\circ} \mathrm{C}\right)$ till assayed.

Multiple doses studies: This study was performed on the same single dose administered group, as ( 6 birds) had been given florfenicol ( $\left.30 \mathrm{mg} \mathrm{kg}^{-1} \mathrm{~b} . \mathrm{wt}\right)$ daily 
for another 5 consecutive days (intra-crop route) whereas, the other ( 6 birds) that previously administered single oral dose had been given vit $\mathrm{E}(2 \mathrm{mg} / \mathrm{kg}$ b.wt.) firstly $2 \mathrm{~h}$ before starting florfenicol administration then florfenicol (30 $\mathrm{mg} \mathrm{kg}^{-1}$, b.wt) daily for another 5 consecutive days (intra-crop route). In both groups the blood samples had been collected at the last day of drugs dosing ( $5^{\text {th }}$ day). Blood samples $(1 \mathrm{ml}$ each) were taken from wing vein just after 5,10,15,30 minutes, 1,2,4,6,8,12,24,48,72 and 96 hrs post-drug administrations. Also all blood samples were left to clot for 30 minutes, centrifuged at 3000 r.p.m. for 15 minutes and the obtained clear serum was transferred to eppendorff's tubes and kept in deep freeze $\left(-20^{\circ} \mathrm{C}\right)$ till assayed.

\section{Assay for florfenicol}

Florfenicol concentrations in plasma were evaluated by a microbiological agar plate assay using Bacillus subtilis (ATCC 25922) as the test organism [17]. Standard curve of florfenicol in healthy broiler chickens were linear over the range of $0.02-25 \mu \mathrm{g} / \mathrm{ml}$. The diameter of the inhibition zones $(\mathrm{mm})$ were linear when plotted against of concentration of florfenicol $(\mu \mathrm{g} / \mathrm{ml})$ with correlation coefficient of 0.995 in normal chicken serum, 0.995 in distilled water. Estimation of protein binding tendency of florfenicol was carried by preparing a standard solution in distilled water and also in normal antibiotic free chicken>s serum at concentrations of florfenicol 0.02,0.04,0.09,0.1,0.3 (reference concentration), $0.6,1.75,3.125,6.25,12.5,25 \mu \mathrm{g} / \mathrm{ml}$. The differences in the diameter of inhibition between the solutions of the drugs in the distilled water (buffer) and that in serum of the chickens were used to calculate the percentage of protein binding of the tested antibacterial according to the following equation [18].

Protein binding $\%=$ Zone of inhibition in buffer-Zone of inhibition in serum $\quad \mathrm{x} 100$

Zone of inhibition in buffer

\section{Pharmacokinetic analysis}

Serum concentrations of florfenicol versus time curve were formed and best fitted by the aid of computer poly-exponential curve stripping program. Data from each chicken were fitted individually and the pharmacokinetic variables were calculated by the aid of the software programs. The hybrid rate constants of distribution and elimination phase $\left(\alpha\right.$ and $\beta$ ), the first order absorption and elimination rate constants $\left(\mathrm{K}_{\mathrm{ab}}\right.$ and $\left.\mathrm{K}_{\mathrm{el}}\right)$ and corresponding extrapolated zero time intercepts (A and B), absorption, distribution and elimination half-lives $\mathrm{t}_{0.5(\mathrm{ab}),} \mathrm{t}_{0.5(\mathrm{e}) \text { ), }}$ the area under the curve from zero to infinite time (AUC 0-œ), mean residence time (MRT), maximum serum concentration $\left(\mathrm{C}_{\max }\right)$ and time to be achieved $\left(\mathrm{t}_{\max }\right)$ were calculated. The results were expressed as Mean $\pm \mathrm{S}$.E and the obtained data statistically using Student"t" test [19].

\section{Results}

Single oral administration of florfenicol alone or pre-treated with vit E (florfenicol-vit E combination): (Effects of vit E on the disposition kinetics of florfenicol after single oral administration)

The mean serum concentrations of florfenicol alone or pre-treated with vit $\mathrm{E}$ after single oral administration in healthy broiler chickens at different time intervals at a dose of $30 \mathrm{mg} / \mathrm{kg}$ b.wt. Are shown in table 1, figure 1 . The mean serum concentrations of the drug are markedly lower in single florfenicol alone as compared with florfenicol pre-treated with vit $\mathrm{E}$ at the corresponding time intervals. The maximum concentration of the drug in serum was $6.46 \mathrm{ug} / \mathrm{ml}$ in florfenicol alone whereas $7.48 \mathrm{ug} / \mathrm{ml}$ in florfenicol pre-treated with vit $\mathrm{E}$. The all pharmacokinetic parameters are recorded in table 2 showed that the serum concentrations were higher after florfenicol pre-treated with vit $\mathrm{E}$ when compared to the florfenicol alone.

Multiple oral administration of florfenicol alone or pre-treated with vit E (florfenicol-vit E combination): (Effects of vit E on the disposition kinetics of florfenicol after repeated oral administration)

The mean serum concentrations of florfenicol alone or pre-treated with vit $\mathrm{E}$ after 
multiple oral administration in healthy broiler chickens at different time intervals at a dose of $30 \mathrm{mg} / \mathrm{kg}$ b.wt. (florfenicol) and $2 \mathrm{mg} / \mathrm{kg}$ b.wt. (vit E) are shown in table 3, figure 2 . The mean serum concentrations of the drug are markedly lower in multiple florfenicol alone as compared with florfenicol pre-treated with vit E after repeated dosing at the corresponding time intervals. The maximum concentration of the drug in serum was $7.47 \mathrm{ug} / \mathrm{ml}$ in florfenicol alone whereas, $8.38 \mathrm{ug} / \mathrm{ml}$ in florfenicol pretreated with vit E. The pharmacokinetic parameters are recorded in table 4) showed that the serum concentrations were higher after florfenicol pre-treated with vit $\mathrm{E}$ when compared to the florfenicol alone.

Table 1: Mean Serum concentrations of florfenicol alone or pre-treated with vit $E(\mathrm{ug} / \mathrm{ml})$ in healthy broiler chickens after single oral administration of $30 \mathrm{mg} / \mathrm{kg}$ (florfenicol) and $2 \mathrm{mg} / \mathrm{kg}$. b.wt (vit E) $(\mathrm{n}=6)$.

\begin{tabular}{|c|c|c|}
\hline \multirow{2}{*}{ Time } & \multicolumn{2}{|c|}{ MeantS.E } \\
\hline & florfenicol & florfenicol-vit E \\
\hline $5 \mathrm{~min}$ & - & $0.61 \pm 0.14^{\star \star \star}$ \\
\hline $10 \mathrm{~min}$ & $0.73 \pm 0.11$ & $0.87 \pm 0.1^{\star \star}$ \\
\hline $15 \mathrm{~min}$ & $1.66 \pm 0.32$ & $1.56 \pm 0.28^{\star}$ \\
\hline $30 \mathrm{~min}$ & $2.94 \pm 0.32$ & $2.97 \pm 0.4$ \\
\hline $1 \mathrm{~h}$ & $6.46 \pm 0.70$ & $5.39 \pm 0.4^{\star \star}$ \\
\hline $2 \mathrm{~h}$ & $5.19 \pm 0.65$ & $7.55 \pm 0.3^{\star \star \star}$ \\
\hline $4 \mathrm{~h}$ & $3.62 \pm 0.64$ & $6.14 \pm 0.4^{\star \star \star}$ \\
\hline $6 \mathrm{~h}$ & $2.02 \pm 0.45$ & $4.72 \pm 0.4^{\star \star \star}$ \\
\hline $8 \mathrm{~h}$ & $0.99 \pm 0.22$ & $2.35 \pm 0.3^{* \star \star}$ \\
\hline $12 \mathrm{~h}$ & $0.34 \pm 0.06$ & $0.94 \pm 0.1 * \star$ \\
\hline $24 \mathrm{~h}$ & $0.16 \pm 0.02$ & $0.39 \pm 0.11$ ** \\
\hline $48 \mathrm{~h}$ & & $0.18 \pm 0.03^{\star \star \star}$ \\
\hline \multicolumn{3}{|c|}{ Significant at: ${ }^{* \star \star} P \leq 0.001, * \star P \leq 0.01, * P \leq 0.05$} \\
\hline
\end{tabular}

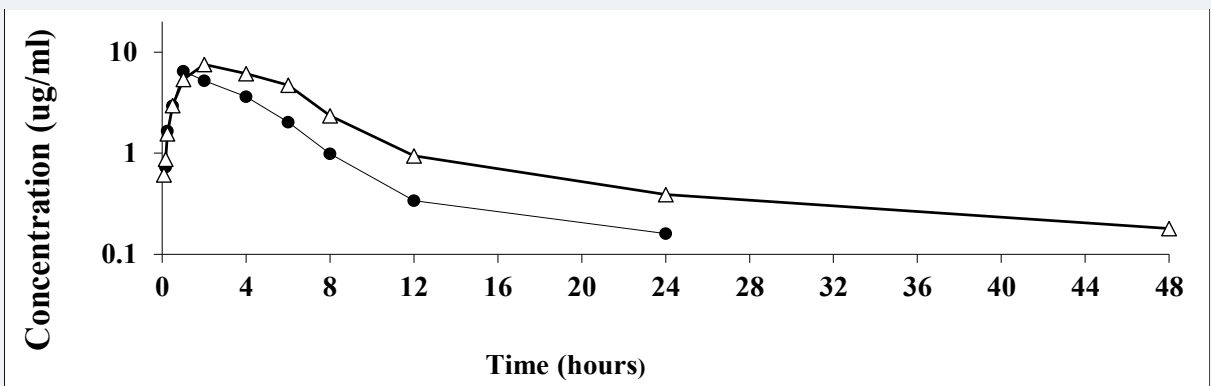

Figure-1: Semilogarithmic plot depicting the time-course of florfenicol ( $\bullet$ ) and florfenicol-vit $E(\boldsymbol{\Delta})$ combination in serum after single oral administration of 2 $\mathrm{mg} / \mathrm{kg}$ b.wt.(vit E) and $30 \mathrm{mg} \mathrm{kg}^{-1}$ b.wt.(florfenicol).

Figure 1: Patient 24, varying maximum activity in visual comparison of I-131 scintigram (1a) with the $\mathrm{Tc}-99 \mathrm{~m}-\mathrm{O}_{4}$ scintigram (1b). Grid image in Figure 1a highlighted by the use of a high-energy collimator.

Table 2: Pharmacokinetic parameters of florfenicol alone or pre-treated with vit $E$ in healthy broiler chickens following a single oral administration of $30 \mathrm{mg} / \mathrm{kg}$ and $2 \mathrm{mg} / \mathrm{kg}$ b.wt. (vit E) $(\mathrm{n}=6)$.

\begin{tabular}{|c|c|c|c|}
\hline kinetic parameters ${ }^{1}$ & Unit & florfenicol & florfenicol-vit E \\
\hline$A$ & $\mathrm{ug} / \mathrm{ml}$ & $10.30 \pm 2.8$ & $11.9 \pm 1.6$ *夫 \\
\hline$K_{(a b)}$ & $\mathrm{h}^{-1}$ & $1.28 \pm 0.33$ & $0.98 \pm 0.14^{*}$ \\
\hline$t_{0.5 \mathrm{ab}}$ & $\mathrm{h}$ & $0.51 \pm 0.11$ & $0.71 \pm 0.1^{*}$ \\
\hline $\mathrm{B}$ & $\mathrm{ug} / \mathrm{ml}$ & $9.8 \pm 2.9$ & $11.9 \pm 1.6^{\star \star \star}$ \\
\hline $\mathrm{K}_{\mathrm{el}}$ & $h^{-1}$ & $0.26 \pm 0.03$ & $0.16 \pm 0.02^{*}$ \\
\hline $\mathrm{t}_{0.5 \mathrm{el}}$ & $\mathrm{h}$ & $2.72 \pm 0.34$ & $4.34 \pm 0.5^{\star \star \star}$ \\
\hline$t_{\max }$ & $\mathrm{h}$ & $1.40 \pm 0.09$ & $2.42 \pm 0.19 * \star$ \\
\hline $\mathrm{C}_{\max }$ & $\mathrm{ug} / \mathrm{ml}$ & $5.9 \pm 0.46$ & $7.48 \pm 0.3^{\star \star \star}$ \\
\hline AUC & $\mu g . h . m l$ & $31.3 \pm 3.1$ & $55.9 \pm 5.3^{\star \star \star}$ \\
\hline AUMC & $\mu \mathrm{g} \cdot \mathrm{h} 2 \cdot \mathrm{ml}^{-1}$ & $32.9 \pm 3.2$ & $66.7 \pm 7.5^{\star \star \star}$ \\
\hline MRT & $\mathrm{h}$ & $4.95 \pm 0.89$ & $5.57 \pm 0.7 * \star$ \\
\hline
\end{tabular}

${ }^{1} \mathrm{k}_{\mathrm{ab}}$ first-order absorption rate constant; $\mathrm{K}_{\mathrm{el}}$ elimination rate constant; $\mathrm{C}_{\max }$ maximum serum concentration; $\mathrm{t}_{\max }$ time to peak serum concentration; $\mathrm{t}_{0.5(\mathrm{ab})}$ absorption half-life; $\mathrm{t}_{0.5(\mathrm{el})}$ elimination half-life; MRT mean residence time; AUC area under serum concentration-time curve.

Significance: ${ }^{\star *} P \leq 0.001,{ }^{*} P \leq 0.01, * P \leq 0.05$ 
Table 3: Mean Serum concentrations of florfenicol alone or pre-treated with vit $E$ (ug/ml) in healthy broiler chickens after multiple oral administration of $30 \mathrm{mg} / \mathrm{kg}$ b.wt. (florfenicol) and $2 \mathrm{mg} / \mathrm{kg}$ b.wt. (Vit E) (n=6).

\begin{tabular}{|c|c|c|}
\hline \multirow{2}{*}{ Time } & \multicolumn{2}{|c|}{ MeantS.E } \\
\hline & florfenicol & florfenicol-vit E \\
\hline $5 \mathrm{~min}$ & $0.62 \pm 0.12$ & $0.74 \pm 0.07$ ** \\
\hline $10 \mathrm{~min}$ & $1.04 \pm 0.31$ & $0.93 \pm 0.06 *$ \\
\hline $15 \mathrm{~min}$ & $1.72 \pm 0.26$ & $1.74 \pm 0.31$ \\
\hline $30 \mathrm{~min}$ & $2.83 \pm 0.24$ & $2.90 \pm 0.2^{\star}$ \\
\hline $1 \mathrm{~h}$ & $5.22 \pm 0.43$ & $5.63 \pm 0.5^{\star \star}$ \\
\hline $2 \mathrm{~h}$ & $7.47 \pm 0.45$ & $8.38 \pm 0.3^{\star \star \star}$ \\
\hline $4 \mathrm{~h}$ & $6.3 \pm 0.42$ & $6.81 \pm 0.3^{\star \star}$ \\
\hline $6 \mathrm{~h}$ & $4.56 \pm 0.48$ & 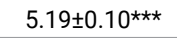 \\
\hline $8 \mathrm{~h}$ & $2.34 \pm 0.21$ & 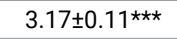 \\
\hline $12 \mathrm{~h}$ & $1.06 \pm 0.14$ & $1.45 \pm 0.1$ ** \\
\hline $24 \mathrm{~h}$ & $0.37 \pm 0.09$ & $0.37 \pm 0.1$ \\
\hline $48 \mathrm{~h}$ & $0.13 \pm 0.03$ & $0.16 \pm 0.04$ \\
\hline $72 \mathrm{~h}$ & - & $0.06 \pm 0.02 * \star \star$ \\
\hline
\end{tabular}

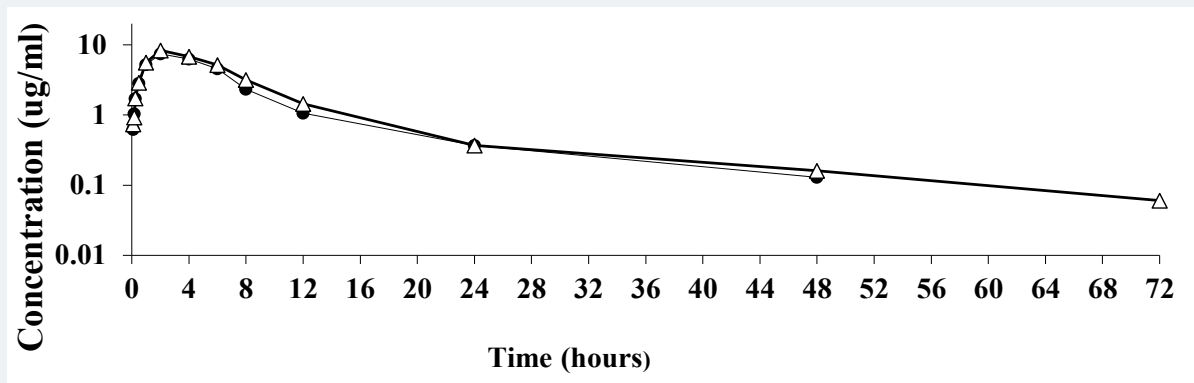

Figure-2: Semilogarithmic plot depicting the time-course of florfenicol (a) and florfenicol-vit $\mathrm{E}(\boldsymbol{\Delta})$ combination in serum after multiple oral administration of 2 $\mathrm{mg} / \mathrm{kg}$ b.wt.(vit E) and 30 mg.kg-1 b.wt.(florfenicol).

Figure 2: Mean serum concentrations of florfenicol alone or in combination with vit $E(\mathrm{ug} / \mathrm{ml})$ in healthy broiler chickens following multiple oral administration of $2 \mathrm{mg} / \mathrm{kg} . b . w t$. and $30 \mathrm{mg} / \mathrm{kg} . \mathrm{b} . \mathrm{wt}$. $(\mathrm{n}=6)$.

Table 4: Pharmacokinetic parameters of florfenicol alone or pre-treated with vit $E$ in healthy broiler chickens following repeated oral administration of $30 \mathrm{mg} / \mathrm{kg}$ b.wt. and $2 \mathrm{mg} / \mathrm{kg}$ b.wt. $(\mathrm{n}=6)$.

\begin{tabular}{|c|c|c|c|}
\hline kinetic parameters $^{1}$ & Unit & florfenicol & florfenicol-vit E \\
\hline $\mathrm{A}$ & $\mathrm{ug} / \mathrm{ml}$ & $13.3 \pm 1.23$ & $13.4 \pm 2.1$ \\
\hline $\mathrm{K}_{(\mathrm{ab})}$ & $\mathrm{h}^{-1}$ & $0.83 \pm 0.04$ & $0.85 \pm 0.04^{\star}$ \\
\hline $\mathrm{t}_{0.5 \mathrm{ab}}$ & $\mathrm{h}$ & $0.82 \pm 0.04$ & $0.81 \pm 0.04$ \\
\hline $\mathrm{B}$ & $\mathrm{ug} / \mathrm{ml}$ & $12.75 \pm 1.14$ & $12.9 \pm 2.1^{\star}$ \\
\hline $\mathrm{K}_{\mathrm{el}}$ & $\mathrm{h}^{-1}$ & $0.18 \pm 0.01$ & $0.16 \pm 0.02^{\star}$ \\
\hline $\mathrm{t}_{0.5 \mathrm{el}}$ & $\mathrm{h}$ & $3.77 \pm 0.2$ & $4.52 \pm 0.7^{\star \star \star}$ \\
\hline $\mathrm{t}_{\max }$ & $\mathrm{h}$ & $2.3 \pm 0.1$ & $2.5 \pm 0.05^{\star}$ \\
\hline $\mathrm{C}_{\max }$ & $\mathrm{ug} / \mathrm{ml}$ & $7.4 \pm 0.3$ & $8.04 \pm 0.3^{\star \star \star}$ \\
\hline $\mathrm{AUC}$ & $\mu \mathrm{g} \cdot \mathrm{h} \cdot \mathrm{ml}$ & $54.4 \pm 2.2$ & $63.5 \pm 1.9^{\star \star \star}$ \\
\hline $\mathrm{AUMC}$ & $\mu \mathrm{g} \cdot \mathrm{h}^{2} \cdot \mathrm{ml}^{-1}$ & $64.6 \pm 4.5$ & $78.29 \pm 2.4^{\star \star \star}$ \\
\hline $\mathrm{MRT}$ & $\mathrm{h}$ & $5.13 \pm 1.1$ & $6.9 \pm 1.8^{\star \star \star}$ \\
\hline
\end{tabular}

${ }^{1} \mathrm{k}_{\mathrm{ab}}$ first-order absorption rate constant; $\mathrm{K}_{\mathrm{el}}$ elimination rate constant; $\mathrm{C}_{\text {max }}$ maximum serum concentration; $\mathrm{t}_{\max }$ time to peak serum concentration; $t_{0.5(a b)}$ absorption half-life; $t_{0.5(e)}$ elimination half-life; MRT mean residence time; AUC area under serum concentration-time curve.

Significance: ${ }^{* *} P \leq 0.001,{ }^{* *} P \leq 0.01,{ }^{*} P \leq 0.05$

Florfenicol alone after single and multiple oral administrations in broiler chickens

The mean serum concentrations of florfenicol at different time intervals following single and multiple oral administration of $30 \mathrm{mg} / \mathrm{kg} \mathrm{b.wt}$. in (12) broiler chickens were presented in table 5 and depicted in figure 3 . The drug was firstly detected $0.73 \pm 0.11$, $0.62 \pm 0.12 \mathrm{ug} / \mathrm{ml}$ after 10 and $5 \mathrm{~min}$ and the maximum serum level $6.46 \pm 0.70$ and $7.47 \pm 0.45 \mathrm{ug} / \mathrm{ml}$ was reached at 1 and $2 \mathrm{~h}$ after single and multiple administrations. 
Table 5: Mean Serum concentrations of florfenicol alone $(\mathrm{ug} / \mathrm{ml})$ in healthy broiler chickens following a single and multiple oral administration of $30 \mathrm{mg} / \mathrm{kg}$ b.wt. for 5 successive days $(\mathrm{n}=6)$.

\begin{tabular}{|c|c|c|}
\hline \multirow{2}{*}{ Time } & Single & Mean \pm S.E \\
\hline $5 \mathrm{~min}$ & - & multiple \\
\hline $10 \mathrm{~min}$ & $0.73 \pm 0.11$ & $0.62 \pm 0.12^{\star \star \star}$ \\
\hline $15 \mathrm{~min}$ & $1.66 \pm 0.32$ & $1.04 \pm 0.31^{\star \star}$ \\
\hline $30 \mathrm{~min}$ & $2.94 \pm 0.32$ & $1.72 \pm 0.26^{\star}$ \\
\hline $1 \mathrm{~h}$ & $6.46 \pm 0.70$ & $2.83 \pm 0.24^{\star}$ \\
\hline $2 \mathrm{~h}$ & $5.19 \pm 0.65$ & $5.22 \pm 0.43^{\star \star \star}$ \\
\hline $4 \mathrm{~h}$ & $3.62 \pm 0.64$ & $7.47 \pm 0.45^{\star \star \star}$ \\
\hline $6 \mathrm{~h}$ & $2.02 \pm 0.45$ & $6.3 \pm 0.42^{\star \star \star}$ \\
\hline $8 \mathrm{~h}$ & $0.99 \pm 0.22$ & $4.56 \pm 0.48^{\star \star \star}$ \\
\hline $12 \mathrm{~h}$ & $0.34 \pm 0.06$ & $2.34 \pm 0.21^{\star \star \star}$ \\
\hline $24 \mathrm{~h}$ & $0.16 \pm 0.02$ & $1.06 \pm 0.14^{\star \star \star}$ \\
\hline $48 \mathrm{~h}$ & & $0.37 \pm 0.09 *$ \\
\hline Significant: $* \star * P \leq 0.001, * \star P \leq 0.01, * P \leq 0.05$. & & $0.13 \pm 0.03^{\star \star \star}$ \\
\hline
\end{tabular}

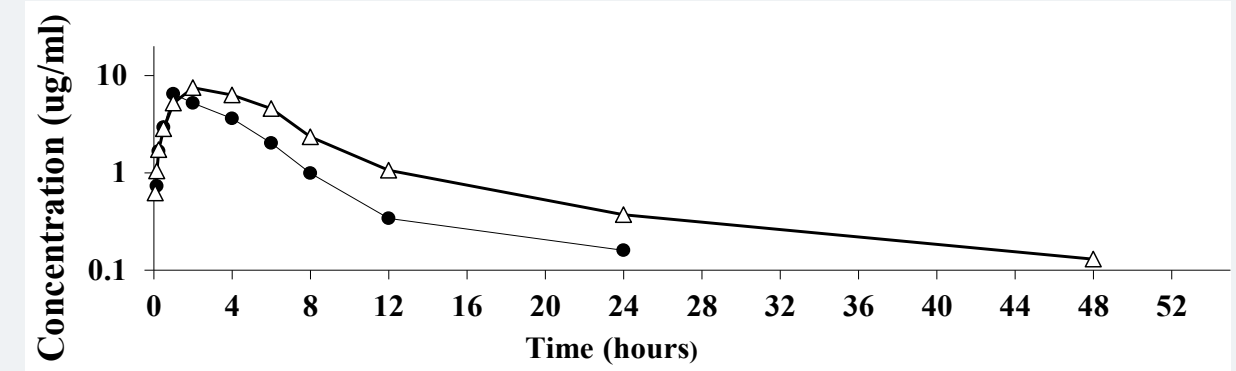

Figure-3: Semilogarithmic plot depicting the time-course of florfenicol in serum after single ( $\boldsymbol{-}$ ) and multiple ( $\boldsymbol{\Delta}$ ) oral administration of $30 \mathrm{mg} \cdot \mathrm{kg}^{-1}$ b.wt.

Figure 3: Mean serum concentrations of florfenicol alone $(\mathrm{ug} / \mathrm{ml})$ in healthy broiler chickens following a single and multiple oral administration of $30 \mathrm{mg} / \mathrm{kg}$. $(\mathrm{n}=6)$.

The pharmacokinetic parameters are tabulated in table 6 . The peak concentration $\left(\mathrm{C}_{\max }\right)$ was $5.9 \pm 0.46,7.4 \pm 0.3 \mathrm{ug} / \mathrm{ml}$ and the calculated value of $\mathrm{t}_{\max }$ was $1.4 \pm 0.09$, $2.3 \pm 0.1 \mathrm{~h}$ respectively. The absorption half-life $\left(\mathrm{t}_{0.5 \mathrm{ab}}\right)$ was $0.51 \pm 0.11,0.82 \pm 0.04 \mathrm{~h}$ and eliminated with a mean half-life $\left(\mathrm{t}_{0.5 \mathrm{el}}\right)$ of $2.72 \pm 0.34,3.77 \pm 0.2 \mathrm{~h}$ after single and multiple administration respectively.

\section{Florfenicol pre-treated with vit E after single and multiple oral administrations in broiler chickens}

The mean serum concentrations of florfenicol pre-treated with vit $\mathrm{E}$ at different time intervals following a single and multiple oral administration of $2 \mathrm{mg} / \mathrm{kg}$ b.wt. (vit E) and $30 \mathrm{mg} / \mathrm{kg}$ b.wt. (florfenicol) in (12) broiler chickens were presented in table 7 and depicted in figure 4 . The drug was firstly detected $0.61 \pm 0.14,0.74 \pm 0.07 \mathrm{ug} / \mathrm{ml}$ after $5 \mathrm{~min}$ and the maximum serum level $7.55 \pm 0.3 ; 8.38 \pm 0.31 \mathrm{ug} / \mathrm{ml}$ was reached at 2 hour after the drug administration. The pharmacokinetic parameters of are tabulated in table 8. The peak concentration $\left(\mathrm{C}_{\max }\right)$ was $7.48 \pm 0.3,8.04 \pm 0.3 \mathrm{ug} / \mathrm{ml}$ and the calculated value of $\mathrm{t}_{\max }$ was $2.32 \pm 0.15,2.5 \pm 0.05 \mathrm{~h}$. The drug was absorbed from healthy broilers gut with absorption half-life $\left(\mathrm{t}_{0.5 \mathrm{ab}}\right)$ of $0.71 \pm 0.1,0.81 \pm 0.04 \mathrm{~h}$ and eliminated half-life $\left(\mathrm{t}_{0.5 \mathrm{el}}\right)$ of $4.34 \pm 0.5,4.52 \pm 0.7 \mathrm{~h}$ after single and multiple dosing respectively.

\section{Discussion}

Following a single oral administration of florfenicol alone at a dose of $30 \mathrm{mg} / \mathrm{kg}$ b.wt. The drug was detected in serum $10 \mathrm{~min}$ post-administration $(0.73 \mathrm{ug} / \mathrm{ml})$. It was continued to increase gradually till reach its maximum concentration $6.46 \mathrm{ug} / \mathrm{ml}$ and $\mathrm{C}_{\max } 5.9 \mathrm{ug} / \mathrm{ml}$ at $1 \mathrm{~h}$ post-oral administration and decreased gradually till reach its lower level $(0.16 \mathrm{ug} / \mathrm{ml})$ at $24 \mathrm{~h}$. This result $\left(\mathrm{C}_{\max }\right)$ is similar to that reported for 
Table 6: Pharmacokinetic parameters of florfenicol alone in healthy broiler chickens following a single and multiple oral administration of $30 \mathrm{mg} / \mathrm{kg}$ b.wt. $(\mathrm{n}=6)$.

\begin{tabular}{|c|c|c|c|}
\hline Kinetic parameters $^{1}$ & Unit & Single & Repeated \\
\hline $\mathrm{A}$ & $\mathrm{ug} / \mathrm{ml}$ & $10.30 \pm 2.8$ & $13.3 \pm 1.23^{\star \star \star}$ \\
\hline $\mathrm{K}_{(\mathrm{ab})}$ & $\mathrm{h}^{-1}$ & $1.28 \pm 0.33$ & $0.83 \pm 0.04^{\star \star}$ \\
\hline $\mathrm{t}_{0.5 \mathrm{ab}}$ & $\mathrm{h}$ & $0.51 \pm 0.11$ & $0.82 \pm 0.04^{\star \star}$ \\
\hline $\mathrm{B}$ & $\mathrm{ug} / \mathrm{ml}$ & $9.8 \pm 2.9$ & $12.75 \pm 1.14^{\star \star \star}$ \\
\hline $\mathrm{K}_{\mathrm{el}}$ & $\mathrm{h}^{-1}$ & $0.26 \pm 0.03$ & $0.18 \pm 0.01^{\star}$ \\
\hline $\mathrm{t}_{0.5 \mathrm{el}}$ & $\mathrm{h}$ & $2.72 \pm 0.34$ & $3.77 \pm 0.2^{\star \star}$ \\
\hline $\mathrm{t}_{\max }$ & $\mathrm{h}$ & $1.40 \pm 0.09$ & $2.3 \pm 0.1^{\star \star \star}$ \\
\hline $\mathrm{C}_{\max }$ & $\mathrm{ug} / \mathrm{ml}$ & $5.9 \pm 0.46$ & $7.4 \pm 0.3^{\star \star \star}$ \\
\hline $\mathrm{AUC}$ & $\mu \mathrm{gg} \cdot \mathrm{h} \cdot \mathrm{ml}$ & $31.3 \pm 3.1$ & $54.4 \pm 2.2^{\star \star \star}$ \\
\hline $\mathrm{AUMC}$ & $\mu \mathrm{gg} \cdot \mathrm{h}^{2} \cdot \mathrm{ml}$ & $32.9 \pm 3.2$ & $64.6 \pm 4.5^{\star \star \star \star}$ \\
\hline MRT & $\mathrm{h}$ & $4.95 \pm 0.89$ & $5.13 \pm 1.1^{\star}$ \\
\hline
\end{tabular}

${ }^{1} \mathrm{k}_{\mathrm{ab}}$ first-order absorption rate constant; $\mathrm{K}_{\mathrm{el}}$ elimination rate constant; $\mathrm{C}_{\max }$ maximum serum concentration; $\mathrm{t}_{\max }$ time to peak serum concentration; $\mathrm{t}_{0.5(\mathrm{ab})}$ absorption half-life; $\mathrm{t}_{0.5(\mathrm{el})}$ elimination half-life; MRT mean residence time; AUC area under serum concentration-time curve. Significance: ${ }^{*} * 0 \leq 0.001,{ }^{*} P \leq 0.01,{ }^{*} P \leq 0.05$.

Table 7: Mean Serum concentrations of florfenicol pre-treated with vit $E(\mathrm{ug} / \mathrm{ml})$ in healthy broiler chickens after single and multiple oral administration of $2 \mathrm{mg} / \mathrm{kg}$ and $30 \mathrm{mg} / \mathrm{kg} \mathrm{b.wt.}(\mathrm{n}=6)$.

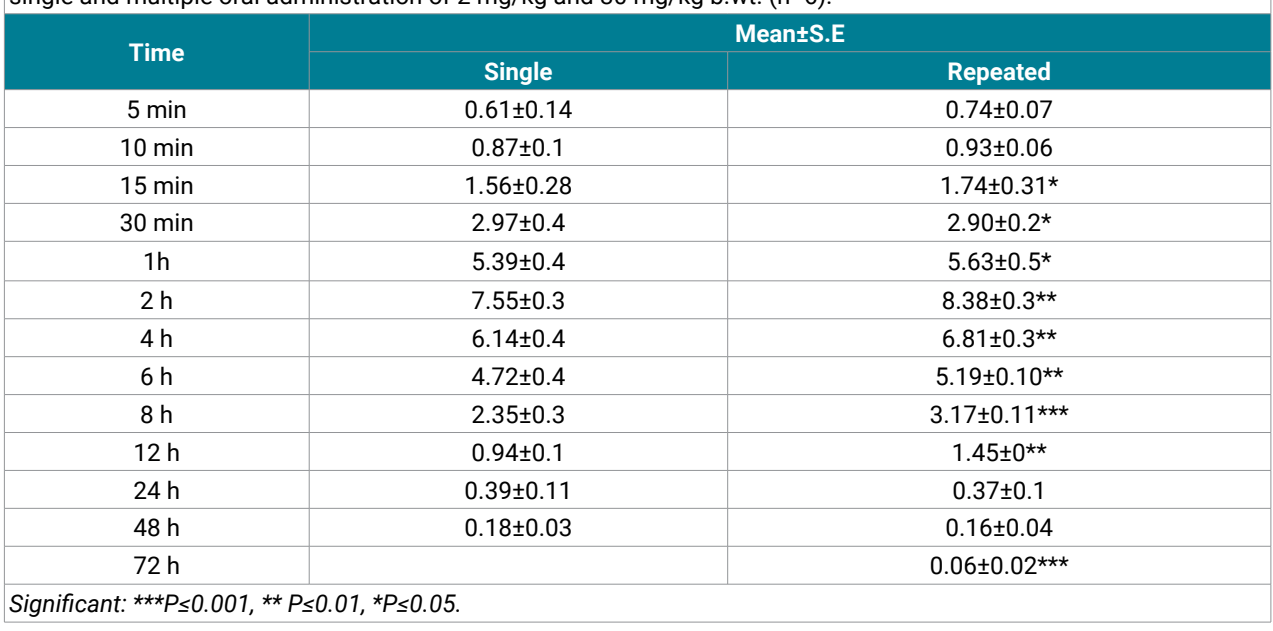

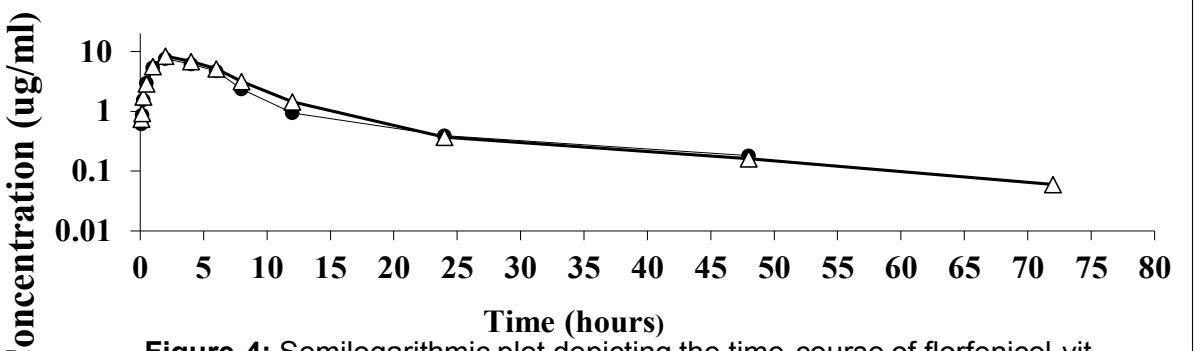

Figure-4: Semilogarithmic plot depicting the time-course of florfenicol-vit

$\mathrm{E}$ combination in serum after single ( $\boldsymbol{\nabla})$ and multiple $(\boldsymbol{\Delta})$ oral administration of $2 \mathrm{mg} / \mathrm{kg}$ b.wt.(vit E) and $30 \mathrm{mg} \mathrm{kg}^{-1}$ b.wt.(florfenicol).

Figure 4: Mean serum concentrations of florfenicol pre-treated with vit $E(\mathrm{ug} / \mathrm{ml})$ in healthy broiler chickens following a single and multiple oral administration of $2 \mathrm{mg} / \mathrm{kg} \mathrm{b.wt}$.(vit E) and $30 \mathrm{mg} / \mathrm{kg}$. $(\mathrm{n}=6)$.

florfenicol in broiler chickens [16] $7.2 \mathrm{ug} / \mathrm{ml}$ [20], $6.79 \mathrm{ug} / \mathrm{ml}$ and [21] (6.8 ug/ml), but slightly lower that that reported by [22] $7.9 \mathrm{ug} / \mathrm{m}$ in infected broiler chickens and this discrepancies attributed to that differences in the method of florfenicol measurements as HPLC used in that study. The drug was rapidly absorbed with an absorption half-life $\left(\mathrm{t}_{0.5 \mathrm{ab}}\right) 0.51 \mathrm{~h}$. Our finding is similar to that reported for the drug in broiler chickens 0.5 $\mathrm{h}$ [22] and $0.37 \mathrm{~h}$. [21] But, slightly different from that reported in foals [24] (0.29 h), this discrepancies may be attributed to species and dose differences and eliminated with elimination half-life $\left(\mathrm{t}_{0.5 \mathrm{e}}\right)$ was $2.72 \mathrm{~h}$., similar to that reported for florfenicol in broiler chickens by [22], $2.25 \mathrm{~h}$ but lower than that reported by [21], 3.8 and higher 
Table 8: Pharmacokinetic parameters of florfenicol pre-treated with vit $E$ in healthy broiler chickens following a single and multiple oral administrations of $2 \mathrm{mg} / \mathrm{kg} . \mathrm{b} . w \mathrm{wt}$ and $30 \mathrm{mg} / \mathrm{kg}$ b.wt. $(\mathrm{n}=6)$.

\begin{tabular}{|c|c|c|c|}
\hline kinetic parameters $^{1}$ & Unit & Single & repeated \\
\hline A & $\mathrm{ug} / \mathrm{ml}$ & $11.9 \pm 1.6$ & $13.4 \pm 2.1^{\star \star \star \star}$ \\
\hline $\mathrm{K}_{(\mathrm{ab})}$ & $h^{-1}$ & $0.98 \pm 0.14$ & $0.85 \pm 0.04^{*}$ \\
\hline $\mathrm{t}_{0.5 \mathrm{ab}}$ & $\mathrm{h}$ & $0.71 \pm 0.1$ & $0.81 \pm 0.04^{*}$ \\
\hline B & $\mathrm{ug} / \mathrm{ml}$ & $11.9 \pm 1.6$ & $12.8 \pm 2.1^{\star \star \star}$ \\
\hline $\mathrm{K}_{\mathrm{el}}$ & $h^{-1}$ & $0.16 \pm 0.02$ & $0.16 \pm 0.02$ \\
\hline $\mathrm{t}_{0.5 \mathrm{el}}$ & $\mathrm{h}$ & $4.34 \pm 0.5$ & $4.52 \pm 0.7^{\star \star \star \star}$ \\
\hline$t_{\max }$ & $\mathrm{h}$ & $2.42 \pm 0.19$ & $2.5 \pm 0.05^{\star \star \star}$ \\
\hline $\mathrm{C}_{\max }$ & $\mathrm{ug} / \mathrm{ml}$ & $7.48 \pm 0.3$ & $8.04 \pm 0.3^{\star \star \star}$ \\
\hline AUC & $\mu \mathrm{g} . \mathrm{h} . \mathrm{ml}$ & $55.9 \pm 5.3$ & $63.5 \pm 1.9 * \star \star$ \\
\hline AUMC & $\mu \mathrm{g} \cdot \mathrm{h}^{2} \cdot \mathrm{ml}^{-1}$ & $66.7 \pm 7.5$ & $78.29 \pm 2.4^{\star \star \star}$ \\
\hline MRT & $\mathrm{h}$ & $5.57 \pm 0.7$ & $6.9 \pm 1.8^{\star \star \star}$ \\
\hline
\end{tabular}

${ }^{1} \mathrm{k}_{\mathrm{ab}}$ first-order absorption rate constant; $\mathrm{K}_{\mathrm{el}}$ elimination rate constant; $\mathrm{C}_{\max }$ maximum serum concentration; $\mathrm{t}_{\max }$ time to peak serum concentration; $t_{0.5(a b)}$ absorption half-life; $t_{0.5(\text { el) }}$ elimination half-life; MRT mean residence time; AUC area under serum concentration-time curve. Significance: ${ }^{*} * P \leq 0.001,{ }^{*} P \leq 0.01,{ }^{*} P \leq 0.05$

than [25] $\mathrm{t}_{0.5 \mathrm{el}} 1.41 \mathrm{~h}$., that's may be attributed to the difference in drug formulation. The in-vitro protein binding tendency of florfenicol in serum is $13.00 \%$, similar to that reported by [5] $16.8 \%$ in broiler chickens but slightly lower than that reported by [16] $18.6 \%$ that may be due to different drug formulation.

The results obtained showed lower plasma concentrations of florfenicol alone as compared with florfenicol pre-treated with vit $\mathrm{E}$ following the drug administration at different time intervals as, florfenicol pre-treated with vit $\mathrm{E}$ was detected in serum 5 minutes post-administration $(0.61 \mathrm{ug} / \mathrm{ml})$, It was continued to increase gradually till reach its maximum concentration $\left(\mathrm{C}_{\max }\right) 7.55 \mathrm{ug} / \mathrm{ml}$ at $2 \mathrm{~h}$ post-administration and decreased gradually till reach its lower level $0.18 \mathrm{ug} / \mathrm{ml}$ at $48 \mathrm{~h}$. These results explained on that increasing the absorption rates and serum accumulation offlorfenicol pre-treated with vit E [4], who informed that florfenicol accumulated after multiple administration leading to increase in the maximum serum concentration than the single florfenicol alone, as $\mathrm{C}_{\max }$ was higher in florfenicol pre-treated with vit $\mathrm{E}$ than single florfenicol alone in broiler chickens in addition, absorption half-life $\left(\mathrm{t}_{0.5 \mathrm{ab}}\right)$ in florfenicol pre-treated with vit $\mathrm{E}$ was $0.71 \mathrm{~h}$ where as in florfenicol alone was $0.51 \mathrm{~h}$, vit $\mathrm{E}$ helps rapid absorption of florfenicol besides, increasing the absorption rate and serum concentration might be due to binding of vit $\mathrm{E}$ with part of plasma proteins lead to high concentration of free drug in the serum so increasing its serum level in addition, vit $\mathrm{E}$ decrease the renal excretion on binding proteins through renal infiltration that's may bind with part of the drug leading also to increase its serum concentration as reported by [26] about effects of vit $E$ on renal function in rats in addition [21], found that vitamins as vit $C$ increasing the serum concentrations of antibiotics when combined with them. Vit $E$ combination with florfenicol leads to more prolonged $\left(\mathrm{t}_{0.5 \mathrm{e}}\right)$ of $4.34 \mathrm{~h}$ in the body than single florfenicol $(2.72 \mathrm{~h})$ alone leading to more prolonged effects of florfenicol in the serum that's may attributed to that the majority of florfenicol excretion and its highly accumulate mainly in kidney and liver [21] after repeated dose of florfenicol and [28], whose informed that florfenicol accumulated rapidly in the kidney and liver besides the main elimination route of vitamins through the kidney and the liver $[29,30]$, so the capacity of the eliminated organs might be saturated at the elimination of vit $\mathrm{E}$ firstly which might lead to accumulation of part of the florfenicol more prolonged in the body till be eliminated so increasing its elimination half-lives besides the hepatoprotective effect of vit $E[31,32]$. The combination of florfenicol with vit $E$ allows a prolongation of the dosage intervals in broiler for 24 hours so this important combination allows the interval to be prolonged to more $24 \mathrm{~h}$ indicated by long elimination half-life $\left(\mathrm{t}_{0.5 \mathrm{e}}\right)$ and MRT in florfenicol pre-treated with vit $\mathrm{E} 4.34,5.57 \mathrm{~h}$ as compared to $3.8,4.95 \mathrm{~h}$ in the single dose administration of florfenicol alone.

Following multiple administration of florfenicol alone, the drug reach its maximum concentration $(7.47 \mathrm{ug} / \mathrm{ml})$ at $2 \mathrm{~h}$ post-administration, this result is higher than 
the single florfenicol alone administration. This result explained on that increasing the absorption rates and serum accumulation of the drug after multiple dosing leading to increase in the maximum serum concentration than the single one [4] indicated by the low absorption half-life $\left(\mathrm{t}_{0.5 \mathrm{ab}}\right) 0.51 \mathrm{~h}$ in single dosing as compared to $0.82 \mathrm{~h}$ in multiple dosing chickens, florfenicol was rapidly absorbed with an absorption half-life $\left(\mathrm{t}_{0.5 \mathrm{ab}}\right)$ of $0.82 \mathrm{~h}$ which was higher than the result reported for single administration $0.51 \mathrm{~h}$ which also indicates accumulation of part of the drug in the serum [4]. Florfenicol was eliminated at slower rate $(P<0.05)$ in multiple dosing than single administration as indicated by long elimination half -life $\left(\mathrm{t}_{0.5(\mathrm{ell})}\right)$ and residence time (MRT) in repeated dosing 3.77 and $5.13 \mathrm{~h}$ compared to 2.71 and $4.95 \mathrm{~h}$ in the single dose administration, repeated dosing allows a prolongation of the dosage intervals in broiler for 24 hours these results similar to that reported by [21] of florfenicol in broiler chickens. In addition [28,33], informed that florfenicol accumulated rapidly in the kidney and liver and its main elimination route through the kidney and the liver so after repeated dosing of florfenicol and its accumulation in the serum, the kidney capacity for elimination would decreased till complete elimination so lead to prolonged of the elimination rates.

Following multiple oral administration of florfenicol pre-treated with vit $\mathrm{E}$ the drug was detected in serum 5 minutes post oral administration $(0.74 \mathrm{ug} / \mathrm{ml})$. It was continued to increase gradually thereafter to reach its maximum concentration $\left(\mathrm{C}_{\max }\right) 8.38 \mathrm{ug} / \mathrm{ml}$ at $2 \mathrm{~h}$ post-admimstration and reached its lower level $(0.16 \mathrm{ug} / \mathrm{ml})$ at $48 \mathrm{~h}$. This result $\left(\mathrm{C}_{\text {max }}\right)$ was higher than single dose administration of florfenicol pre-treated with vit E (7.48 ug/ $\mathrm{ml}$ ) indicates serum accumulation of part of the drug in the serum [4]. Vitamins play a role in increasing the serum concentrations of antibiotics [27]. This result explained on that increasing the absorption rates and serum accumulation of the drug after vit $\mathrm{E}$ combination with repeated dosing leading to increase in the maximum serum concentration than the single dose administration of florfenicol-vit $\mathrm{E}$ alone as indicated by the absorption halflife $\left(\mathrm{t}_{0.5 \mathrm{ab}}\right)$ after repeated dosing $0.81 \mathrm{~h}$ was slightly higher than florfenicol-vit $\mathrm{E}$ single administration $0.71 \mathrm{~h}$ that's may due accumulation of parts of the drug after absorption in organs and in serum [20]. The drug was rapidly absorbed after oral administration with an absorption half-life $\left(\mathrm{t}_{0.5 \mathrm{~b}}\right) 0.82 \mathrm{~h}$ which is higher than single florfenicol pre-treated with vit $\mathrm{E}$ indicates that vit $\mathrm{E}$ after multiple dosing increase the absorption rates than single dose administration. florfenicol pre-treated with vit $\mathrm{E}$ after multiple dosing lead to prolonged $\left(\mathrm{t}_{0.5 \mathrm{e}}\right)$ of $4.52 \mathrm{~h}$ than single florfenicol-vit E $(4.34 \mathrm{~h})$ leading to more prolonged effects of florfenicol in the serum that's may attributed to the hepatoprotective effect of vit $E[31,32]$ and renal and hepatic elimination of both drugs that's interfere with their elimination [29], besides the serum accumulation of part of the drug in the serum and the vit $\mathrm{E}$ effects on plasma protein excretion $[4,21]$. The combination of florfenicol and vit $\mathrm{E}$ with multiple dosing allows a prolongation of the dosage intervals in broiler for 24 hours so this important combination allows the interval to be prolonged to more one day of the drug to be effective, so florfenicol eliminated at slower rate $(P<0.05)$ pre-treated with vit $\mathrm{E}$ after multiple dosing than given single dose indicated by long elimination half -life $\left(\mathrm{t}_{0.5(\mathrm{ell})}\right)$ and residence time (MRT) in florfenicol pre-treated with vit E (multiple dosing) 4.52 and $6.9 \mathrm{~h}$ compared to 4.3 and $5.5 \mathrm{~h}$ in the single dose administration of florfenicol pre-treated with vit $\mathrm{E}$. We conclude that florfenicol pre-treated with vit $\mathrm{E}$ either after single or multiple oral administrations leading to increase in the serum concentration of florfenicol for 24 and $48 \mathrm{~h}$ respectively than single and multiple oral administration of florfenicol alone indicated by longer elimination half-life and mean residence time (MRT) which increase the tissue and serum concentrations of the drug leading to increase its efficacy but not toxicity as florfenicol of wide safety margin and of low toxic level.

\section{Acknowledgements}

The authors acknowledge Pharmacology Department, Faculty of veterinary Medicine, Beni-Suef University for their help in birds rearing. This work has been performed by the authors of their own interest. 


\section{References}

1. Lis M, Szczypka M, Suszko A, Świtala M, Obminska-mrukowicz B. The effects of florfenicol on lymphocyte subsets and humoral immune response in mice. Polish J Vet Sci. 2011; 14: 191-198. Ref.: https://goo.gl/sPnJbh

2. Papich MG, Riviere JE. Chloramphenicol and derivatives, macrolides, lincosamides and miscellaneous antimicrobials. Vet Pharmacol and Therap lowa State and miscellaneous antimicrobials. 2011; 868897.

3. Koc F, Ozturk M, Kadioglu Y, Dogan E, Yanmaz LE, et al. Pharmacokinetics of florfenicol after intravenous and intramuscular administration in New Zealand white rabbits. Res Vet Sci. 2009; 87: 102-105. Ref.: https://goo.gl/qV6jKy

4. Holmes K, Bedenice D, Papich MG. Florfenicol pharmacokinetics in healthy adult alpacas after subcutaneous and intramuscular injection. J Vet Pharmacol Ther. 2012; 35: 382-388. Ref.: https://goo.gl/31FhQo

5. Chang SK, Davis JL, Cheng CN, Shien RH, Heleh MK, et al. Pharmacokinetics and tissue depletion of florfenicol in Leghorn and Taiwan Native chickens. J Vet Pharmacol Therap. 2010; 33: 471-479. Ref.: https://goo.gl/kCir38

6. Edwards DJ. Beneficial Pharmacokinetic Drug Interactions. Adv Pharmacoepidem Drug Safety. 2012; S1: 2.

7. Daniel E, Becker DDS. Adverse Drug Interactions. Anesth Prog. 2011; 58: 31-41.

8. Hegerova $\mathrm{E}$, imunek J. Influence of coccidiostats on the pharmacokinetics of orally administered sulphonamides. $4^{\text {th }}$ Congress of the EAVPT. 1988; 66.

9. Lashev L. Pharmacokinetics of apramycin and sulpha-chlor pyridazine co-administered with flavorphospholipol and avoparcin to chickens. Bulg J Vet Med. 1998; 1: 71-76. Ref.: https://goo.gl/AafE4X

10. Moutafchieva R. Effects of some nutritive antibiotics on the pharmacokinetics of tylosin in chickens. Vet sbirka (Bg). 1989; 3: 19-22.

11. Ramadan A, Hanafy MS, Afifi NA. Effect of pantotenic acid on disposition kinetics and tissue residues of sulphadimidine in chickens. Res Vet Sci. 1992; 52: 337-341. Ref.: https://goo.gl/aDnPQK

12. Sharmanov T. Ascorbic acid. In: Experimentally vitaminology. (Ostrovski, U., Ed.), Minsk, Science and Technology. 1979; 481-500.

13. Maliha SS, Shahed MJ, Janker MN, Abasi KW, Nigm-Rahman AE. Clinical and experimental evidences in antibiotics side effects and toxicity associate with overdose and long-term of use. Pharmacol Assoc J. 2009; 6: 23-31.

14. Velanganni AJ, Balasundaram C. Protective effect of vitamin A, ascorbic acid and a-tocopherol on 2,4- dimethylaminoazobenzene-induced hepatoma in rats. Current Sci. 2003; 85: 201- 203. Ref.: https://goo.gl/vh8jwu

15. Ukpanukpong RU, Eteng MU, Dasofunj OK. Antioxidant interactions of Pefloxacin, garlic, vitamins $C$ and $E$ on lipid profile level of albino wistar rats. J App Pharm Sci. 2013; 3: 167-170. Ref.: https://goo.gl/c9hNve

16. Afifi NA, Abo El-Sooud KA. Tissue concentrations and pharmacokinetics of florfenicol in broiler chickens. Brt Poult Sci. 1997; 38: 425-428. Ref.: https://goo.gl/2fHnvM

17. Abd El-Aty AM, Goudah A, Abo El-Sooud K, El-Zorba HY, Shimoda M, et al. pharmacokinetics and bioavailability of florfenicol following intravenous, intramuscular and oral administration in rabbits. Vet Res Commun. 2004; 28: 515-524. Ref.: https://goo.gl/rwkDnj

18. Craig AW, Suh B. Protein binding and the antibacterial effects. Method for the determination of protein binding. In: Lorain, V.(Ed.). Antibiotics in Laboratory Medicine. 1991; 367-402.

19. Sendecor GW, Cochran WG. Statistical methods. $7^{\text {th }}$ Ed. The lowa State University, Press Ames, lowa, USA. 1981.

20. Dingfei $\mathrm{H}$, Jianzhong S, Xianai W. Pharmacokinetics of florfenicol in Broiler Chickens. Acta Vet et Zootech Sinica. 2002; 33: 384-388. Ref.: https://goo.gl/wKNGKf

21. El-Banna HA, El-Zorba HY. Pharmacokinetics of florfenicol (Water soluble formulation) in healthy 21 and Pasteurella infected broiler chickens. World Rur Obs. 2011; 1: 13-19. Ref.: https://goo.gl/ScfDQS

22. Shen J, Wu X, Hu D. Pharmacokinetics of florfenicol in healthy and Escherichia-coli infected broiler chickens. Res vet sci. 2002; 37: 137-140. Ref.: https://goo.gl/4TwZsn 
23. Shen J, Hu D, Wu X. Bioavailability and pharmacokinetics of florfenicol in broiler chickens. J Vet Pharmacol Ther. 2003; 26: 337-341. Ref.: https://goo.gl/wKmBNf

24. Tohamy MA, Radi AM. Bioavilability and pharmacokinetics of Florfenicol in healthy foals. J Egypt Soc Pharmacol Exp Ther. 2008; 29: 529-538.

25. Abu-Basha EAH, Gehring R, Al-Shunnaq AF. Pharmacokinetics and Bioequivalence of florfenicol Oral Solution Formulations (Flonicol ${ }^{\circledR}$ and Veterin $\AA 10 \%$ ) in Broiler Chickens. J Bioequiv Availab. 2012; 4: $1-5$.

26. El-hadjela D, Zine K, Leila B. The beneficial effect of combined administration of vitamins $C$ and $E$ on renal function and selected parameters of antioxidant system in diabetic rats fed zinc-deficient diet. Africa J Biotech. 2013; 12: 6232-6240. Ref.: https://goo.gl/JqkwQg

27. Haritova AM, Lashev LD. Pharmacokinetics of olendamycin administered alone and after oral ascorbic acid in three bird species. Veterinarski Arhiv. 2003; 73: 199-210. Ref.: https://goo.gl/F3Tkwm

28. Yang Q, Xie L, Wu Z. Pharmacokinetics of florfenicol after oral administration in yellow catfish, Pelteobagrus fulvidraco. J World Aquacul Soc. 2013; 44: 586-592. Ref.: https://goo.gl/LdPFjQ

29. Giroud A, Leblond CP. Histological study of renal elimination of ascorbic acid. Anat Rec. 1973; 68: 113. Ref.: https://goo.gl/EofjN8

30. Ralli EP, Friednan GJ, Rubin SH. The mechanism of vitamin C by the human kidney. J Clin Invest.1938; 17: 765-770. Ref.: https://goo.gl/Fq5a7z

31. Attia HF, Soliman MM, Ismail TH. Protective Effect of Vitamin E and Selenium on the liver, heart and aorta. J Vet Anat. 2012; 5: 17-29. Ref.: https://goo.gl/5vhvzL

32. Uboh FE, Ebong BK, Akpan HD, et al. Hepatoprotective effect of vitamins $\mathrm{C}$ and $\mathrm{E}$ against gasoline vapor-induced liver injury in male rats. Turk J Biol. 2012; 36: 217-223. Ref.: https://goo.gl/beZLMs

33. Liu J, Fung K, Chen Z, Zeng Z, Zhang J. Pharmacokinetics of Florfenicol in Healthy Pigs and in Pigs Experimentally Infected with Actinobacillus pleuropneumoniae. Antimicrob agents Chemother. 2003; 47: 820-823. Ref.: https://goo.gl/tNKQvP 